\title{
Vocational Training for Rural Populations: A Demand-Driven Approach and its Implications in India
}

\author{
Muthuveeran Ramasamy, Matthias Pilz \\ University of Cologne, Herbert-Lewin-Str. 2, 50931 Cologne, Germany
}

Received: 26.09.2019, Accepted: 22.04.2020, Published: 07.10.2020

\begin{abstract}
Context: Vocational training is viewed as a significant tool that increases employment outcomes and provides potential career advancement opportunities for individuals. Many countries are witnessing a shift from supply-driven to demand-driven approaches. The demand-driven approach in vocational training is often explored at the macro level and is associated with the perspectives of employers and labour markets. In contrast, this article explores the demand-driven approach at the micro level by focusing on the perspectives of individual learners within the context of their localities in order to position them at the centre of the skill development process.

Methods: This study used a qualitative exploratory research method and a mixture of focus group and face-to-face semi-structured interviews to obtain data to identify the practical problems that arise in real life contexts when attempts are made to prioritise vocational training demands in line with the needs of all the stakeholders. Based on the demand from the targeted learners, a competency-based vocational training course especially for women was designed, tested and evaluated in selected villages.

Findings: The results show clearly that the demands of the rural population varied, and their participation in the training course was highly influenced by access to a training centre, the duration of the training, economic returns and socio-cultural factors. The demand-driven approach works best in vocational training when it involves the relevant stakeholders and the target groups in the planning and designing process.
\end{abstract}

*Corresponding author: matthias.pilz@uni-koeln.de 
Conclusion: The findings illustrate that demand-driven approach should be context specific, responsive to individuals'/learners' demands, relevant and flexible.

Keywords: VET, Vocational Education and Training, Vocational Training, Demand-Driven Approach, India, Needs Assessment, Women

\section{Introduction}

The notion of a "demand-driven" approach has gained importance in the development strategies of international development and donor agencies (Carney et al., 2007). The term "demand" has a similar meaning to need, want and desire, however, demand is a distinct approach that used in a different context (Ramasamy, 2016, p. 31-39). In many countries, the concept of a "demand-driven" approach in Vocational Training (VT) is gaining momentum and reforms are taking place (King, 2012; Majumdar, 2008; Kingombe, 2012; Wallenborn, 2010). These reforms are accompanied by advantages and disadvantages according to country policies and implementation mechanisms. Current supply-demand approaches to traditional VT are presumed to be inadequate for delivering the competences required by the labour market (McGrath, 2012; Pavlova \& Maclean, 2013). Another key point to remember is that many of the VT programmes in the past were considered as supply-driven due to insufficient adaptation of the training strategies of employers and/or state agencies, socioeconomic conditions and institutional frameworks which failed to meet the emerging market needs (Keating, 2009; Mehrotra et al., 2013; Tara et al., 2016). In contrast, the demand-driven approach as used in the context of international development reflects the notion of personal well-being, quality life of individuals including an effect on attitude, motivation and personality, and the development of a society (Bennell, 1999).

The concept of a demand-driven approach in VT is often discussed in the literature (Keating, 2009) and in other empirical studies as skill demand in the labour market, which response to changes in the technological and economic environment. These studies pertain mainly to the macro level of the demand-driven approach, which is mostly connected to industrial, labour market and/or employers' demand. It can be argued that access to training mostly remains limited to the formal VT sector which does not meet the needs of the illiterate, less-educated and the poor. Against this backdrop, our study focuses on the demand-driven approach of VT from the perspectives of individuals, learners and society by keeping them at the centre of the vocational skill development process. Specifically, we explore to what extent the demand-driven approach of VT is possible and its implications for a rural population. We examined this empirically through a pilot vocational skills training programme in India.

This paper highlights three major aspects which include: VT demands of the targeted group; individuals'/learners' needs; factors influencing those (vocational) training needs; and 
the response to those demands. To set this in the research context, we first provide a brief description of the "demand-driven" discourse in the research literature relevant to this study. We also define our own understanding of the concept of "training demand" relating to the conditions of rural South-India. In the next section, we frame the study in the context of skilling the rural labour force in India. This is followed with a description of our study design and methods. We then discuss and analyse the results of the study. The outcomes are discussed in the light of other findings and the VT programme design.

\section{Definitions of the Demand-Driven Approach in the Research Literature}

Most of the studies on VT from a development perspective (Anderson, 2003; Bennel, 1999; King, 2012; Kingombe, 2012; Maxwell et al., 2000; Palmer, 2015) have provided ample evidence that many developed and developing countries have realised and witnessed the transition from supply-driven to demand-driven approaches to meet the current economic and technological challenges. In most of the countries, VT is viewed from economic aspects and focuses on employability and productivity (McGrath, 2012) that primarily correspond to industry and enterprises' expectations. This perspective generally gives little importance to the needs of individuals and regional/societal demands and, hence, does not consider the learners/target group with due importance in the (learning) process.

Palmer's (2015) study of countries in the Pacific region has noted that the funding regimes of VT systems are based on the supply-driven training model. This top-down approach does not adapt to market needs, and, hence, the resultant training strategies remain supply-driven. In order to make VT more equitable, demand-driven, responsive and relevant, Palmer (2015) argues that financing programmes need to be strongly linked to policy objectives. Similarly, Majumdhar (2011) has asserted that VT in the Asia Pacific region has been supply-driven and has had limited impact on the labour market. He argues for a needs-based approach using labour market information to overcome the problem of skill mismatch.

In Sub-Saharan African countries, where the (formal) VT system has been largely supplydriven, the implementation process of such programmes has dominated and impeded the development of transparent, demand-driven and low-cost training markets (Palmer, 2007; Ziderman, 2003). The training markets have failed to develop due to labour market imperfections (i.e. insufficient incentives exist for employees and individuals to invest in training) on both the demand and supply side.

Stockmann and Silvestrini (2011) examined the VT programmes supported by the German Technical Cooperation (GIZ) in its partner countries. They found that factors such as relevance, efficiency and sustainability were not sufficiently present to enable the achievement of the intended goals. Further, they argued that the lack of systematic need identifi- 
cation and stakeholder analysis, poor planning and implementation were the main reasons which made the programmes supply-driven.

The above literature reviews make it clear that VT systems tend not to give importance to the demand of individuals or societal perspectives and also often even fail to meet local employer needs. Many experts (Goovaerts et al., 2005; Mkandawire, 2001; Rakodi \& LloydJones, 2002) in the fields of extension, community development organisations, aid-agencies and practitioners of human resource development often use the "demand-driven" approach in relation to individual demand. They believe that it enhances social inclusion, access to disadvantaged groups in a society and facilitates education, training, and (self-) employment. However, only minimal attention has been paid to the demand side from the individuals' and/or target groups' point of view (Bennell, 1999; International Labour Organization [ILO], 2011, 2012; Mitra, 2002; Wallenborn, 2014). This includes lack of awareness of the vocational career aspirations of individuals, meeting learner or target group preferences, and considering their capabilities from a pedagogical perspective at the micro level (Maitra \& Mani, 2014; Noronha \& Endow, 2011).

Therefore, it is worth exploring how a demand-driven approach to VT at the grassroots level might support and respond to the individual demands of rural people in India by considering their needs beyond those of employers and the wider labour market.

The rationale of the "demand-driven" approach as used in this paper is a "bottom-up" method of designing a programme with the active participation of the target group and relevant stakeholders. It refers to "decentralisation" of participatory decision making in a real-life context, which helps to improve any education and training programme, and focuses on contextually appropriate strategies for the learners or target groups (Ramasamy, 2016). Further, the growing economic and technological changes in the labour market require individuals to play a greater role in and take more responsibility for choosing their own education, training and career development in their lives, based on the political and social context and their personal aspirations (Anderson, 2003; Arulmani, 2009). In many developing countries, there is an increasing attention on the process of shifting education and training systems to a demand-driven approach to take account of the learners'/clients' perspectives (Ramanujam \& Sodhi, 2010). Similarly, it is argued that vocational skills training systems should increase learning opportunities for specific target groups to enhance their employment outcomes and address the challenges such as entry-level qualifications, affordable cost, and access by school dropouts and disadvantaged learners (Schofield, 1996). In this way, it is proposed that the system can support the demand from individuals and encourage training providers to respond. In addition, this approach can increase the degree of determination in an individual to realise their goals and take appropriate decisions about their vocational learning. To portray this with respect to Maxwell et al's (2000) terms, this approach is closely associated with a VT framework that is relevant and based on the real-life context of learners. Thus, it is es- 
sential that VT should address the social objectives of the deprived, less-educated and rural populations as well as industry priorities (Ramasamy, 2016; Fisher, 1993). Mutso (2007) calls this a "consumerist approach" where the learners choose VT (and the providers they want to study with) in the competitive labour market because their skills and abilities vary, which in turn affects their career choice. Thus, the proposed bottom-up approach is said to be more flexible and responsive to the needs of local people, students, employers and communities. By contrast, the centralised approach has been criticised for not sufficiently considering the education and training needs of individuals and/or learners' preferences (Rupasingha et al., 2000; Schofield, 1996). Consequently, the bottom-up approach encourages training providers to organise VT programmes in consultation with learners, communities and other key stakeholders. Further, it increases efficiency with flexibility and is also connected with local culture, social needs and market realities, including options of self-employment and entrepreneurship (Mitra, 2002; Ramasamy, 2016). More importantly, this approach can respond to deprived learners who will have or have had little or limited formal education and training (Ramasamy, 2016; Mitra, 2002). As Billett (2000) asserts, meeting the demands of people and/or stakeholders beyond only those of enterprises is one of the most important principles of VT. To sum up, we define the demand-driven approach in this study as follows. Demanddriven VT identifies and meets the endogenous needs of potential target people and/or learners in rural areas through decentralised, active participation. The potential target learners will be involved in planning and designing process of VT programmes which is tailored to fit their real-life context and have relevance. More importantly, VT should respond to the prioritised needs of its intended target group in terms areas of interest, flexibility, accessibility, affordability, in the light of their social realities and circumstances.

\section{Pilot Intervention in the Indian Context}

To gain a better understanding of the socio-economic environment in which our study took place, we give a short overview of the research context and situation of rural India. India is a developing country with the potential to become one of the largest economies in the world. In order to achieve such development and to meet the needs of labour markets locally and globally, the country would require an adequate number of skilled and semi-skilled people to provide quality goods and services (Chenoy, 2013). Therefore, VT is considered as one of the significant means to accelerate the supply of a quality workforce, enhance productivity, and help individuals to attain gainful employability and improve their earnings (Agrawal \& Agrawal, 2017; Pilz, 2016). As mentioned in the introduction, the demand for skills in the Indian labour market in various emerging sectors and in manpower planning has been studied by many scholars and organisations (Agrawal \& Indrakumar, 2014; Institute of Applied Manpower Research, 2012; McKinsey Global Institute, 2012; Mehrotra \& Saxena, 2014; Ministry of 
Labour and Employment [MoLE], 2010). As the country is facing structural changes in the economy, it is essential to tap the opportunity afforded by the demographic dividend of so many young people entering the workforce in the next twenty years. Another main factor is that around $70 \%$ of the Indian population is living in rural areas as the country remains predominantly an agrarian-based society. The agricultural sector has seen reasonable growth in the five decades since independence in spite of a substantial increase in agricultural production. However, the general livelihood of the rural population still remains low (Mehrotra \& Saxena, 2014). Further, it is noted that during the last two decades employment in agriculture fell by 14 million and is moving to non-agriculture activities (Mehrotra \& Saxena, 2014; Parida, 2015). It is essential to point out that the current growth in employment is mainly urban-centred and has failed to incorporate the vast majority of the rural population and other less developed sections of the society (Mehrotra et al., 2013). These arguments clearly indicate that a broad shift in the occupational structure of the Indian economy, from farm to non-farm, has created demand for new skill requirements among the emerging workforce (Srivastava, 2008; Tara et al., 2016). This has led to migration of youth from rural to urban areas for profitable employment. Therefore, VT is considered to be an important means to realise the twin objectives of creating skills for the future and for providing livelihood opportunities for young people, rural populations and disadvantaged people (Singh, 2012). Whilst details of the formal Indian vocational education and training system can be found elsewhere (e.g. Wessels \& Pilz, 2018; Pilz, 2016; Schneider \& Pilz, 2019; Anderson \& Lightfoot, 2019), it is important to note here that in many parts of rural India there is no formal vocational education and training system (Sodhi \& Wessels, 2016). Rather, informally organised training structures dominate (Sodhi, 2014; Pilz \& Wilmshöfer, 2015). This underlines the need for demand-driven approaches to locally adapted training in rural areas.

\section{$4 \quad$ Study Design and Methods}

The study focused on Tamil Nadu, South India, which is the sixth largest state by population in India. This region has a number of industrial clusters including electronics, auto components, leather, textiles, heavy industries, food processing, IT and healthcare. The secondary and tertiary sectors have been major drivers of economic growth in this region. These economic developments and changes in the labour market have created more demand for skilled people to enhance productivity and raise business profits to the next level. Moreover, this scenario influences labour market requirements and changes in rural areas where people have difficulties in accessing VT (Regel \& Pilz, 2019). A flexible mode of training curriculum is required to achieve the individuals' demands in terms of field of interest, duration of training, competence requirements, and the need to find either standard or self-employment. The study took place in four villages. These were selected because they represent typical rural 
communities which lack accessibility in terms of road, transport, and (training) infrastructure and the opportunity to participate in economic activities for income generation. Three villages were located in a less-developed region and one was located in an industrial region. We selected the combination of these regions to assess the similarities and differences of VT demands and to examine how the geo-economic conditions affect the demand in these regions. The selection process and the field approach were supported by local experts in training and realised over four-month duration. The study used an exploratory research method and a mixture of focus group discussions and face-to-face semi-structured interviews (Murti \& Bino, 2014) to obtain the data we required to identify: a) The practical problems in real-life situations; b) the contextual factors; and c) prioritise the VT demands in line with the needs of all the stakeholders. Further, it was important to consider the learners' personal VT demands.

In total, four focus group interviews with 45 participants ( 23 male, 22 female) and 15 face-to-face interviews ( 8 male and 7 female) were conducted by a research team combining international research experience and local expertise, including regional culture and language competencies. The selection process in the villages followed a random approach combined with access and willingness of the participants. To enable the research team to gain insights from a sufficiently broad range of people, the respondents for both focus group and face-toface interviews were comprised of community members of all ages, including, young people, village leaders, and representatives of Non-Governmental Organisation (NGO) and Farmers Association. It was important to include both male and female interviewees to enable exploration of gender issues in local labour market needs. The elders and local village leaders are rich resources of information to understand the economic and employment trends, available infrastructures and resources for education and training in their respective villages. Similarly, views of young people may be different regarding current labour market trends and their vocational career choices and aspirations may be different.

The details of demographic information, current education and training infrastructure, the role of NGOs in VT, local employment scenarios and migration for jobs, aspirations to learn a particular vocation and expectations of the training were discussed in the focus group discussions. Each discussion lasted between 45 minutes and 90 minutes. The individual interviews lasted between 30 minutes and 45 minutes and were audio recorded for the purpose of preserving and transcribing. The transcripts were analysed using an inductive process, thereby aggregating the central training needs, the demands concerning the shape of training activities and their rationale. All central training needs were backed up with anchor examples in the form of original quotations, which are listed below in extracts.

Our analysis of the data showed that there was considerable demand for sewing as a VT need among the surveyed villages. The focus on sewing limited our approach to some extent, as traditions in the rural areas mean that sewing as a semi-profession is female dominated. 
Furthermore, the labour market in rural areas is characterised as less-regulated and no proper system exists to identify the labour market demand in villages. Thus, the bottom-up approach focusing on only individuals' employment demand reflects employment opportunities in the local labour market. Therefore, we developed over a time period of 1.5 years a demand-driven sewing vocational course based on a competence-based curriculum and tailor-made teaching and learning materials as an intervention strategy (Ramasamy \& Pilz, 2019). This was piloted in four villages.

\section{$5 \quad$ Findings and Analyses}

In this section, we will first present the findings of the needs assessment survey followed by the results of the pilot intervention study. We then discuss the results of the research as a whole.

\subsection{Findings of the Needs Assessment Survey}

The needs assessment survey in the selected regions identified varied VT demands from individuals. The analysis of the data showed that there were no big differences between the villages. However, we could only find slight variations of training demands. In three villages, beside sewing, leather product making, and automobile repair, some young people also cited air-conditioning and refrigeration maintenance, masonry and carpentry.

As mentioned before, a large proportion of the Indian population lives in rural areas with a high amount of people employed in the informal sector (Palanithurai \& Seerangarajan, 2018; Pilz et al., 2015; Pilz \& Wilmshöfer, 2015; Singh, 2005; Sodhi, 2014; Koops \& Pilz, 2019). The low level of education in the labour force and especially people engaged in agriculture has rendered it harder to provide the needed VT. Also, there is an increasing shift in the labour market from agriculture to manufacturing and service sectors (Mehrotra et al., 2013). The quotes below, from our individual interviews and focus groups, illustrate this shift in the labour market:

Livestock can be provided for the present generation to generate income and vocational skills such as leather products manufacturing, tailoring can be offered to the young people in the villages. (Farmer [father] A1)

Construction is one of the income fetching jobs here and many low and uneducated people go as mason in the construction field. (Youth B1)

The leather shoe tailoring training which even can be work from home by job orders from shoe companies. (Women [mother] A1) 
Non-farm employment is one of the key factors for economic development in rural areas. The decline in agriculture has caused diversified livelihood opportunities for rural people (Parida, 2015). Indeed, most young people in the 15-35 age group are asking for adequate skills through education and training to enter the productive workforce (Mehrotra \& Saxena, 2014). The above examples illustrate that some parents, whose occupation is farming, do not want their children to continue in a farming occupation, and it also shows that young and older people exploring non-farm vocational skills. The respondent in one village, where many leather-based industries are located, indicated that more opportunities for self-employment are needed. It implies that training demand is closely linked to local labour market conditions and it is believed that it could provide (self-) employment outcomes (Agrawal \& Agrawal, 2017).

Due to the fact that we selected sewing as the vocational area for our pilot with women aged between 18-60 years as targeted learners, we now discuss some implications about the special role of women in the rural areas are important to recognise (Palanithurai \& Seerangarajan, 2018; Ramanujam \& Sodhi, 2010).

Analysing the female learners' local socio-economic conditions and their role in the family is one of the important factors in designing such VT. Moreover, learners, especially women, choose skills that align well with family circumstances. They mostly prefer to work from home and their participation in VT tends to be limited. Despite such issues, the poor and marginalised show interest in acquiring and/or participating in VT. While the choice of VT is often influenced by economic benefits and better (self-) employment opportunities, women respondents, in all the four villages, reported that they wished to learn sewing.

If you offer training on tailoring, it will, even if we are not stitching for others, we can at least use those skills to make blouse for our own use and could save Rs. 40 per blouse. (Women A2)

If my daughter knows tailoring, she can do this tailoring job even if she gets married and goes to her husband's place where she could work from home and look after her family as well. Today, the labour charge is Rs. 30 per blouse, if she stitches minimum of four blouses per day, she can make Rs. 120 in a day. Is it not enough? (Women B1)

The main reason is that traditionally women in rural areas are responsible for domestic work and receive very little support and motivation from their families, which impedes their participation and employment opportunities (Sandhaas, 2005). It is important, therefore, that training providers consider social dynamics, history and traditional norms of the people they target for their courses (Noronha \& Endow, 2011).

Another advantage of VT is that it has the potential in supporting human resource development, economic growth and social development processes in the country to also improve the quality of life (Eichhorst et al., 2015). Therefore, one of the main arguments is that the de- 
mand for training in sewing was highly influenced by the anticipated (self-) employment and earnings of the individuals. When they learn and start sewing, it will yield returns in many ways such as an increase in earnings, improved self-confidence and social status (Ramasamy, 2016; Regel \& Pilz, 2019; Maitra \& Mani, 2014). With a greater demand for sewing blouses in rural areas, trainees have an opportunity to earn more. Some trainees also said that they could save the labour charge on tailoring if they sewed their blouses themselves.

We paid Rs. 25/- to sew a blouse, the sewing cost is increased to Rs. 40/- and Rs. 80/for an ordinary blouse and lining respectively. (Trainee $\mathrm{C} 1$ )

Tailor is asking Rs. 40/- to sew a blouse, but if we learn sewing ourselves we can save this money. Normally they [tailors] charge Rs. 100/- to sew one blouse. I will be able to sew myself, Rs. 100/- is saving for me. (Trainee B1)

These quotes provide further evidence that the economic benefit on completing the training was one of the primary objectives of the trainees. The income generation and local labour market conditions are important factors triggering the demand for specific VT in rural areas. It was evident especially among unemployed and underemployed people (Lent et al., 1994). This supports the claim that needs assessment at the micro level involving individuals, end users and communities sheds light on the general demand of a specific region and local labour market/enterprises (Stockmann \& Silvestrini, 2011).

\subsection{Findings of the Pilot Study}

The 200-hour pilot course was based on a competency-based curriculum including providing teaching and learning materials related to learners' needs with inputs from sewing experts. The pilot training was conducted by trainers who had experience in providing sewing training for rural people and were familiar with a practice-oriented approach. Due to the fact that tailoring deals with some sensitive components like anatomy and body measurements, the gender of the trainers was an important criterion in selecting them and therefore we decided to deploy only female trainers for the pilot study. All four training centres (one in each village) were equipped with sewing machines and necessary tools.

The piloted sewing training was evaluated shortly after the intervention to examine whether the course had met the trainees' demands as articulated in the interviews and focus group discussions. Several evaluation models exist in the literature (Fretwell, 2003; Stufflebeam, 2000). Kirkpatrick's (1967) four-level framework is one of the most popular and commonly applied frameworks for summative evaluation, focusing on training outcomes and assesses the benefits of training to individuals and organisations. He distinguished the four-level framework as: (1) Reaction - participants' emotional reaction to the training; (2) Learning - acquisition of knowledge, skills and attitude change by attending training; 
(3) Behaviour - application of knowledge, skills and attitudes acquired from training at a workplace; and (4) Results - the organisational impact of training. According to Grohmann and Kauffeld (2013) level 1, reaction, is often divided into affective responses and utility, in other words, satisfaction with training and perceived training utility which is helpful for evaluating the short-term outcomes. Hence, we analysed the findings from our study using level 1 of the four levels. Wang and Wilcox (2006) claim that obtaining leaners' feedback in terms of motivation to learn about a specific vocational field will be a more realistic method for measuring trainees' reaction. Thus, we did not evaluate or measure the competencies learnt, but, examined to what extent the two-months' training had met the demands of learners. Also, it is important to consider that most of the trainees who participated in the sewing VT were semi-literate and the training was only a two-month "pilot" programme. Hence, measuring all the variables of the four levels was not realistic as the evaluation was done immediately after the training.

The quality and effectiveness of a training programme can be measured by trainees' motivation (Katansky, 2008). The quantitative data on participation gave a highly positive outcome. In all four villages, a total of 80 women trainees participated in the pilot training (20 in each village). Only two trainees dropped out during the course due to personal reasons.

The following quotations reflect the trainees' perspectives on how the sewing training motivated them to be active participants in the course:

Before starting the [sewing] training, I used to wake-up at six or seven in the morning. But during these two months of training, I gets-up at four or five o' clock in the morning to complete all our domestic work and send kids to school to come for training. So we were very active at that [training] time. (Trainee, B2)

I was going for 100 days [Federal Government Scheme in India] work in my village, but I gave up it to learn this sewing and it is important for us. (Trainee, A1)

The underlying assumption is that trainees believed that sewing training would yield the outcome they desired. As discussed before, motivation to learn is one of the convincing methods to ensure imparted VT is demand-driven. Further, in the skill acquisition process, motivation is considered to be a crucial influencing factor in learning specific vocational skills.

Training location, proximity and access to a training centre, and flexibility in the timing of the training, all played an important role. Indeed, the location of the VT centre played a vital role in enhancing the trainees' participation. In our case, the centres were located directly in the four villages. The majority of the trainees interviewed said that they attended the twomonth sewing training as it was organised in their own village and so was accessible to their houses. 
Access to the [training] centre was very easy as it was located closer to my house. I would have not been permitted [by family members] if the training program was organised somewhere outside of the village. (Trainee B2)

We saved time and bus [transport] cost. If we go outside for training, we have to be on time and also some financial problems [for transport fee] will be there. We wonder if we would have been able to attend the training if it was organised outside of our village. Since this training had been organised nearby [in an accessible place], we had an opportunity to learn. (Trainee C1)

We would have not gone if the training was organised even in our next village. Because we need to take care of our kids, prepare them for schools ... so they [husband] will ask how you will manage domestic work if we go to the training. (Trainee C2)

From the above quotations, it can be argued that the choice of VT centres by the participants was influenced by the proximity to home and the flexible time schedule of the course. As discussed in the earlier section, women's participation in VT often depends on socio-cultural characteristics like marital status, number of children and economic requirements and family support. Similarly, this investigation also confirmed that easy accessibility to a training centre and flexibility around the timing of the course enabled female trainees to participate in sewing training. They were also able to manage their family needs and fulfil social obligations.

Noronha and Endow (2011) argue that reducing barriers such as access to training, cost, education level and flexibility in the training time and location could increase the participation level in VT. Similarly, training which is organised in the trainees' village or in an accessible venue had significant impact on their participation, motivation and maintained their interest throughout the course. The demand-driven sewing training provided adequate socio-personal support to enable the trainees to overcome the obstacles of low-educational level, mobility, socio-cultural norms and domestic responsibilities. The training evaluation also revealed that increased motivation among trainees and self-efficacy resulted in active learning, acquiring knowledge and skills. In this scenario, individuals mostly prefer or takeup an occupation which they regard as giving the most of what they want (Arulmani, 2009), therefore, VT should consider individuals as "consumer groups" in addition to industry groups in the VT market.

The economic theory of education and training also recommends that some portion of the cost needs to be borne by the trainees or participants (Schofield, 1996). Whilst the trainees wanted to extend the training for two more months and were eager to learn further, they were also ready to pay for the training cost, even though in our pilot no charge for training had been included. For example, a few trainees said the following: 
If you arrange a few more machines in the training centre for two more months, we are ready to pay [fees] and learn. We [trainees] are ready to pay salary to the teacher to continue this training to learn more. (Trainee D1)

You give only the machines; we shall pay the salary to teacher and learn it [sewing]. (Trainee C2)

The pilot training offered only initial sewing training as free of cost, so the trainees are willing to pay themselves for further training. According to Garforth (2004), a demand-led approach can reveal that there is a functioning market for service provision in which people voluntarily pay for the service they receive to meet their demand. This is ample evidence that the pilot programme can be said to be demand-driven because the participants were actually ready to contribute or pay for the product or services.

One final point is of interest here. From a pedagogical point of view, we have to define the concept of demand from a different, but also important viewpoint. The teaching style and the methods and learning materials (e.g. instruction sheets) have to be in line with the overall education level and the previous experience of the participants. In our case, many of the trainees were semi-illiterate, so all the teaching materials were designed on the basis of pictures and pictograms. The comments of two trainees underline the necessity of this pedagogical approach:

The trainer taught us well, even if we asked the same questions ten times they explained without any hesitation, she [trainer] never showed angry on us for this. (Trainee, B1)

Our batch has both literate and illiterate people. So when they [trainer] teach us by demonstrating it is understandable for all. So the [trainee'] teaching method can be understood by everyone. (Trainee, B2)

\section{Discussion}

The results of this study indicate that, to design a demand-driven VT programme, some highly important aspects have to be taken into account. We have to ensure the involvement of all relevant stakeholders including potential learners, enterprises, VT providers, in order to understand the varied VT needs that will realise the individuals' employment, career goals and also address local enterprise needs (Billett, 2000). The basic premise of these arguments is that the demand-driven approach has the potential to address a local problem, be accountable, transparent and have an efficiency of providing result-oriented efforts that are more responsive to the learners and targeted population. Our study shows that the cost, entry- level educational qualification, abilities, flexibility in terms of course time, and the access to the 
training venue are critical elements in a demand-driven approach and should be considered while planning for and delivering VT particularly for rural and disadvantaged populations.

Our study offered another interesting dimension. Despite the fact that local people had a very clear view about their VT needs, they were not able to relate their viewpoints to a broader perspective beyond their immediate circumstances. In order to balance the individuals'/ leaners' demands with the local or regional economic conditions and also the demands of the regional labour market, it is very important to involve regional, sectoral and labour market experts in the validation of the data that emerges from the local training needs surveys. This expert knowledge should be considered as an important factor in developing VT programs which are embedded in the regional eco-system and pave the way for sustainable development. In our study, we sometimes found that training demands related to old technologies or sectors of the economy which are no longer suitable for the region (for example missing transport systems for raw materials and delivery of produced goods). In this respect, it is important that demand also takes into account the needs and special characteristics of the local economy and the local labour market conditions. Therefore, at the local level, the initially discussed distinction between individual demand and demand by employers is at least partially eliminated and results in an integrated understanding of demand.

As a consequence, expert knowledge in the design of a demand-driven approach is also needed for a different reason. In some ways, the people we interviewed in the villages were mostly focused only on technical "know-how" and unaware of other important aspects. As a result, some fields of knowledge and dimensions of competences were neglected or undetected. For example, entrepreneurial skills to run a small business were not discussed. To develop successful knowledge and competencies with a long-term impact, we also integrated basic knowledge of price and cost calculation, marketing and also customer interaction (personal skills) to support self-employment and entrepreneurial thinking (Ramasamy \& Pilz, 2019).

We argue that it makes no sense to train using modern technologies of tailoring (for example electronic machinery) if financing an electrical sewing machine is not affordable for the trainees and given that they live in areas experiencing regular power cuts (Regel \& Pilz, 2019).

Women in rural India usually look for female-dominated occupational training because the social and local conditions play an important role in the choice of VT and in the attainment of a vocational career. This underlines the importance of the socio-cultural factors which eventually influence women and other disadvantaged groups to participate in the VT that best suits them. Therefore, VT providers in rural areas have to recognise the primary requirements of learners, including their interest and understand the socio-economic conditions to make the programme more client-oriented and help trainees to improve their conditions (Maxwell et al., 2000). 
A demand-driven approach emphasises the need for discussion and planning with local stakeholders to ascertain the available local resources and for identification of socio-economic opportunities for training delivery. VT providers should adopt more dynamic, innovative approaches and integrate the expressed needs of individuals with local socio-economic development agenda in order to design more effective VT programmes that are demand-driven. Further, this approach of decentralised planning and implementation has provided space to voice the concerns of the disadvantaged community as the demand varies according to the type of industry, availability of business enterprises, training infrastructure, and nature of the geographical locations. These factors play a key role in individuals/learners' access to VT programmes. Despite the advantages of the demand-driven approach, if the participation of the targeted group is low, it would affect the service delivery system of VT. Hence, the VT system should promote the active participation of individuals/learners in the process, in order to enable them to play a significant role in local labour market. Indeed, the trainer in the demand-driven approach plays a substantial, diverse role in meeting the target groups' demands and hence they should be involved in the curriculum development process. Accordingly, for our pilot sewing training, we identified trainers who were experienced in teaching rural people and who were able to impart more of hands-on practical training than theorybased instruction. An orientation programme was conducted for the female trainers to have an overview of the designed curriculum and in the preparation of teaching plans for effective implementation. As discussed in the theoretical framework, in an educational context, a decentralised, demand-driven approach to VT should consider the needs identification, curriculum development, and implementation and evaluation process. Since the individu$\mathrm{al}^{\prime} /$ learners' role is important in educational decision-making, the curriculum development process should also recognise the institutional factors of those associated with enterprise, individual and regional needs (Mayoux, 2005).

In the theoretical part of this paper, we discussed how individuals/learners might be considered as consumers in the training market in terms of their career aspirations, learning attitude, social factors, economic returns and wellbeing, which are important aspects of participation in VT. Similarly, as skills are essential for meeting an individuals'/learners' employment outcomes to increase production and facilitating the growth of a country, policies at the national level that incorporate demand-driven approaches with adequate institutional arrangements to address these issues appropriately are highly needed. While individuals/learners' vary in terms of educational background, income, age and learning abilities, policies should not ignore these disadvantaged rural people and a structured institutional mechanism need to be framed to address these issues appropriately. 


\section{Conclusion}

Our demand-driven sewing training project has its limitations. For example, a cost-benefit analysis was not considered in this study, though this would clearly provide further valuable data with regard to the evaluation of demand-driven initiatives. We did not examine the effect of trainees' social status nor long-term economic development because of the limited data and timeframe. As our approach focused on a pilot study in a limited number of villages in South India, the data cannot be generalised, replicated and transferred without critical reflection to other regions in India or parts of the world. Also, the findings of the study suggest the following directions for future research. A comparative study of similar initiatives within India (if they exist) and in other countries may be helpful to generate further insights on the demand-driven approach.

Nevertheless, the evidence from our study makes a significant contribution to the literature on the relevance and importance of the demand-driven approach to vocational skills training in rural communities. First of all, our work demonstrated that to properly identify the VT demands at the grassroots level especially among a rural and less-educated population, an assessment of individuals'/learners' needs is imperative in addition to identifying the needs of the local labour market. As pointed out at the beginning of this paper, VT needs vary according to the target group's age, level of education, socio-cultural background, income and available infrastructure (Overwien, 2009). In this context, training providers and curriculum planners should keep in mind that a personalised approach is needed while they design VT programmes rather than implementing a pre-designed course or strive to meet conditions imposed by funding agencies (Ramanujam \& Sodhi, 2010; Wallenborn, 2014). Consequently, this training approach enables the VT system to move towards a sector-specific one with adequate institutional arrangements in meeting the current labour market needs.

Secondly, the pilot training course demonstrated that the demand-driven approach is an effective tool to achieve the desired VT needs and that the degree of its success depends on the ability to customise the programme so that it is suitable for the specific context and needs and ability of targeted learners.

Thirdly, the trainers have to play a wider role in meeting the needs of their target groups. In order to have a qualified workforce, it is essential to ensure there is a supply of qualified trainers, especially in a country like India, which needs to shift from a theory-based learning approach to the development of practical skills (Mehrotra \& Saxena, 2014).

As discussed in the introduction, many funded programmes were not effective because they were not relevant to the targeted people due to poor training needs analysis. They were also limited due to their top-down approach, including lack of awareness of available local resources and market situation. This paper articulates identifying VT demands at the grassroots level especially among the rural poor and less-educated. This needs-based assessment is imperative to design and implementation of demand-driven VT considering learners/trai- 
nees real-life context and to meet labour market requirements locally. As Wallenborn (2014) claims, the local targeted people are the experts. They very often know what their skill-needs looks are like and are much more familiar with the challenges of the local and regional economic development.

The findings from this study show that demand-driven VT is more effective when it is based on the participation of the target group, involving them in planning and decisionmaking process of VT programme.

\section{Acknowledgment}

The research project presented here was funded by the programme "New Passage to India: Center for Modern Indian Studies" of the German Academic Exchange Service. We are especially grateful to Prof. em. Dr. Lorna Unwin for her valuable scientific suggestions and comments on the content as well as the linguistic adaptations.

\section{References}

Agrawal, R., \& Indrakumar. (2014). Role of vocational education in shaping socio-economic landscape in India. The Indian Journal of Industrial Relations, 49(3), 483-498. JSTOR. https://www.jstor. org/stable/24546992?seq=1

Agrawal, T., \& Agrawal, A. (2017). Vocational education and training in India: A labour market perspective. Journal of Vocational Education \& Training, 69(2), 246-265. https://doi.org/10.1080/136 36820.2017.1303785

Anderson, D. (2003). Individual learners, choice and lifelong learning. Centre for the Economics of Education and Training. https://hdl.voced.edu.au/10707/150005

Anderson, J., \& Lightfoot, A. (2019). The school education system in India. An overview. British Council. https://www.britishcouncil.in/sites/default/files/school_education_system_in_india_report_2019_final_web.pdf

Arulmani, G. (2009). The internationalization of career counselling: Bridging cultural processes and labour market demands in India. Asian Journal of Counselling, 16(2), 149-170.

Bennell, P. (1999). Learning to change: Skills development among the economically vulnerable and socially excluded in developing countries (Employment and training papers No. 43). International Labour Organisation.

Billett, S. (2000). Defining the demand side of vocational education and training: Industry, enterprises, individuals and regions. Journal of Vocational Education \& Training, 52(1), 5-31. https://doi. org/10.1080/13636820000200104

Carney, S., Bista, M., \& Agergaard, J. (2007). "Empowering" the "local" through education? Exploring community-managed schooling in Nepal. Oxford Review of Education, 33(5), 611-628. https://doi. org/10.1080/03054980701476253 
Chenoy, D. (2013). Public-private partnership to meet the skills challenges in India. In R. Maclean, S. Jagannathan \& J. Sarvi (Eds.), Skills development for inclusive and sustainable growth in developing Asia-Pacific (pp. 181-194). Springer. https://doi.org/10.1007/978-94-007-5937-4_10

Eichhorst, W., Rodríguez-Planas, N., Schmidl, R., \& Zimmermann, F. K. (2015). A road map to vocational education and training in industrialized countries. ILR Review, 68(2), 314-337. https://doi. org/10.1177/0019793914564963

Fisher, N. (1993). Developing a national training market: Is it a sensible strategy? Unicorn, 19(4), 2733.

Fretwell, D. (2003). A framework for evaluating vocational education and training (VET). European Journal of Education, 38(2), 177-190. https://doi.org/10.1111/1467-3435.00137

Garforth, C. (2004). Introduction. In W. Rivera \& G. Alex (Eds.), Demand-driven approaches to agriculture extension: Case studies of international initiatives (pp. 3-7). World Bank.

Goovaerts, P., Gasser, M., \& Inbal, A. B. (2005). Demand driven approaches to livelihood support in post-war contexts. A joint ILO-World Bank study (Social Development Paper No. 89). The World Bank/International Labour Office. https://www.ilo.org/wcmsp5/groups/public/@ed_emp/documents/publication/wcms_115927.pdf

Grohmann, A., \& Kauffeld, S. (2013). Evaluating training programs: Development and correlates of the questionnaire for professional training evaluation. International Journal of Training and Development, 17(2), 135-155. https://doi.org/10.1111/ijtd.12005

International Labour Organization. (2011). Upgrading informal apprenticeship systems. International Labour Organization. https://www.ilo.org/wcmsp5/groups/public/---ed_emp/---ifp_skills/documents/publication/wcms_167162.pdf

International Labour Organization. (2012). TVET reform: Design an inclusive skills development program. International Labour Organization. https://www.ilo.org/wcmsp5/groups/public/---ed_ emp/---ifp_skills/documents/publication/wcms_194704.pdf

Katansky, C. (2008). Quality and effectiveness of vocational training for adults. Bulgarian Journal of Science and Education Policy, 2(1), 107-126. http://bjsep.org/index.php?page=11\&volume_id=1

Keating, J. (2009). Matching supply and demand for skills: International perspectives. Australian Bulletin of Labour, 35(3), 528-560. https://hdl.handle.net/2328/26209

King, K. (2012). The geopolitics and meanings of India's massive skills development ambitions'. International Journal of Educational Development, 32(5), 665-673. https://dx.doi.org/10.1016/j.ijedudev.2012.02.001

Kingombe, C. (2012). Lessons for developing countries from experience with technical and vocational education and training (Working Paper 11/1017 January 2012). International Growth Centre. https://pdfs.semanticscholar.org/6f2a/7ee0909485597ac04b8236fd41cae99b8443.pdf

Kirkpatrick, D. L. (1967). Evaluation of training. In R. L. Craig \& L. R. Bittel (Eds.), Training and development handbook (pp. 87-112). McGraw Hill.

Koops, B., \& Pilz, M. (2019). Skills development in the informal economy: A case study from South India. The Indian Journal of Industrial Relations: A Review of Economic \& Social Development, 54(4), 580-600. https://wipaed.uni-koeln.de/sites/great/GREAT_Dateien/GREAT_in_India/Literatur/ Paper_IJIR_April_2019-2.pdf

Lent, R. W., Brown, D. S., \& Hackett, G. (1994). Toward a unifying social cognitive theory of career and academic interest, choice, and performance. Journal of Vocational Behavior, 45(1), 79-122. https:// doi.org/10.1006/jvbe.1994.1027 
Maitra, P., \& Mani, S. (2014). Learning and earning: Evidence from a randomized evaluation in India. (IZA Discussion Papers No. 8552). IZA.

Majumdar, S. (2008). Work force development in India: Policies and practices. Asian Development Bank Institute. https://www.adb.org/sites/default/files/publication/159351/adbi-workforce-dev-india. pdf

Majumdar, S. (2011). Emerging challenges and trends in TVET in the Asia-Pacific region. Sense Publishers.

Maxwell, G., Cooper, M., \& Biggs, N. (2000). How people choose vocational education and training programs: Social, educational and personal influences on aspiration. National Centre for Vocational Education Research. https://www.ncver.edu.au/_data/assets/file/0015/8016/how-people-choose-494.pdf

Mayoux, L. (2005). Learning and decent work for all: New directions in training and education for propoor growth infocus programme on skills, knowledge and employability. International Labour Organization.

McGrath, S. (2012) .Vocational education and training for development: A policy in need of a theory? International Journal of Educational Development, 32(5), 623-631. https://doi.org/10.1016/j.ijedudev.2011.12.001

McKinsey Global Institute. (2012). Knowledge paper on skill development in India: Learner first. FICCI. https://imyriaads.files.wordpress.com/2013/02/ficci_skill_report_2012.pdf

Mehrotra, S., Gandhi, A., \& Sahoo, K. B. (2013). Estimating India's skill gap on realistic basis for 2022. Economic and Political Weekly, 48(3), 102-111.

Mehrotra, S., \& Saxena, P. K. (2014). The skill development system in India: A reform agenda. In S. Mehrotra (Ed.), India's skill challenge: Reforming the vocational training system to realize the demographic dividend (pp. 246-268). University Press. https://doi.org/10.1093/acprof:o so/9780199452774.003.0008

Mitra, A. (2002). Training and skill formation for decent work in the informal sector: Case studies from South India (Skills Working Paper No. 8). International Labour Organization. https://doi. org/10.13140/RG.2.1.4552.1767

Mkandawire, T. (2001). Social policy in a development context (social policy and development, programme paper number 7, June 2001). United Nations Research Institute for Social Development. https://www.files.ethz.ch/isn/102709/7.pdf

Ministry of Labour and Employment. (2010). Annual report to the people on employment. Ministry of Labour and Employment, Government of India. https://labour.gov.in/annual-reports

Murti, A. B., \& Bino, P. G. D. (2014). Determinants of Skill Shortages in Indian Firms: An Exploration. Indian Journal of Industrial Relations, 49(3), 439-455. https://www.jstor.org/stable/24546989

Mutso, I. (2007). Starting points of vocational career choice of students with special needs: Educational path as a selection analysed through decision making theory. Vadyba/Management, 1(14), 34-41. https://citeseerx.ist.psu.edu/viewdoc/download?doi=10.1.1.506.2417\&rep=rep1\&type=pdf

Noronha, C., \& Endow, T. (2011). Informal training for skilled workers: Issues arising from a qualitative study in four sites in Rajasthan and Madhya Pradesh. International Journal of Training Research, 9(1-2), 110-122. https://doi.org/10.5172/ijtr.9.1-2.110

Overwien, B. (2009). Education and training in the context of poverty reduction. In R. Maclean \& D. Wilson (Eds), International handbook of education for the changing world of work (pp. 2585-2597). Dordrecht. https://doi.org/10.1007/978-1-4020-5281-1_170 
Palanithurai, G., \& Seerangarajan, R. (2018). Informal learning among handloom weavers: A case analysis of Chinnalapatti, Tamil Nadu, India.TVET@Asia, (10), 1-16. https://tvet-online.asia/wpcontent/uploads/2020/03/palanithurai_etal_tvet10.pdf

Palmer, R. (2007). Skills for work? From skills development to decent livelihoods in Ghana's rural informal economy. International Journal of Education Development, 27(4), 397-420. https://doi. org/10.1016/j.ijedudev.2006.10.003

Palmer, R. (2015). Research into the financing of technical and vocational education and training (TVET) in the Pacific. Australian Council for Educational Research. https://www.dfat.gov.au/sites/default/ files/tvet-financing-overview-paper-sustainable-financing.pdf

Parida, J. K. (2015). Growth and prospects of non-farm employment in India: Reflections from NSS data. The Journal of Industrial Statistics, 4(2), 154-168. https://210.212.34.21/handle/32116/2376

Pavlova, M., \& Maclean, R. (2013). Vocationalisation of secondary and tertiary education: Challenges and possible future directions in India. In R. Maclean, S. Jagannathan \& J. Sarvi (Eds.), Skills development for inclusive and sustainable growth in developing Asia-Pacific (Technical and vocational education and training: Issues, concerns and prospects, pp. 46-66). Springer. https://doi. org/10.1007/978-94-007-5937-4_3

Pilz, M. (2016). India: Preparation for the world of work - Education system and school to work transition. Springer VS. https://doi.org/10.1007/978-3-658-08502-5

Pilz, M., Gengaiah, U., \& Venkatram, R. (2015). Skill development in the informal sector in India: The case of street food vendors. International Review of Education, 61(2), 191-209. https://doi. org/10.1007/s11159-015-9485-X

Pilz, M., \& Wilmshöfer, S. (2015). Formal, nonformal, and informal learning in rural India: The case of fishing families on the Chilika Lagoon. Prospects, 45(2), 231-243. https://doi.org/10.1007/s11125015-9338-1

Rakodi, C., \& Lloyd-Jones, T. (2002). Urban livelihoods: A people-centred approach to reducing poverty. Earthscan. https://doi.org/10.1016/S0197-3975(03)00034-1

Ramanujam, M. S., \& Sodhi, J. S. (2010). Skilling women for work in informal sector. Shri Ram Centre for Industrial Relations \& Human Resources.

Ramasamy, M. (2016). Demand-driven approaches in vocational education and training: A case study of rural population in South India. Springer VS. https://doi.org/10.1007/978-3-658-12510-3

Ramasamy, M., \& Pilz, M. (2019). Competency-based curriculum development in the informal sector: The case of sewing skills training in rural South India. International Review of Education, 65(6), 905-928. https://doi.org/10.1007/s11159-019-09810-4

Regel, J., \& Pilz, M. (2019). Informal learning and skill formation within the Indian informal tailoring sector. International Journal of Training Research, 17(2), 140-156. https://doi.org/10.1080/144802 20.2019.1624350

Rupasingha, A., Ilvento, T., \& Freshwater, D. (2000). Demand for skills training in the rural south (TVA rural studies programme, staff paper 00-02). Rural. https://docplayer.net/129125552-Demand-forskills-training-in-the-rural-south.html

Sandhaas, B. (2005). Community based non-formal livelihood skills training for youth and adults in selected regions of Ethiopia (EXPRO). Adult Education and Development, (64), 47-65. https:// www.dvv-international.de/en/adult-education-and-development/editions/aed-642005/iizdvv-asa-workshop/community-based-non-formal-livelihood-skills-training-for-youth-and-adults-inselected-regions-of-ethiopia-expro 
Schneider, S., \& Pilz, M. (2019). The function and institutional embeddedness of polytechnics in the Indian education system. International Journal for Research in Vocational Education and Training, 6(3), 284-308. https://doi.org/10.13152/IJRVET.6.3.5

Schofield, K. (1996). Think local and compete. Review of the role of ACE in the national system of vocational education and training. Australian National Training Authority.

Singh, M. (2005). Introduction. In M. Singh (Ed.), Meeting basic learning needs in the informal sector (pp. 1-22). Springer. https://doi.org/10.1007/1-4020-3427-X

Singh, M. (2012). India's national skills development policy and implications for TVET and lifelong learning. In M. Pilz (Ed.), The future of vocational education and training in a changing world (pp. 179-211). Springer. https://doi.org/10.1007/978-3-531-18757-0_12

Sodhi, J. S. (2014). A study of skill gaps in the informal sector. The Indian Journal of Industrial Relations, 49(3), 456-470. https://www.jstor.org/stable/24546990?seq=1

Sodhi, J. S., \& Wessels, A. (2016). Informal learning: Education and skill development in India's informal sector. In M. Pilz (Ed.), India: Preparation for the world of work (pp. 81-102). Springer. https:// doi.org/10.1007/978-3-658-08502-5_13

Srivastava, R. (2008). Education, skills and the emerging labor market in India. The Indian Journal of Labour Economics, 51(4), 759-782. https://pdfs.semanticscholar.org/1a42/9691c65e52c10c2be647 a93737a3c32c5885.pdf

Stockmann, R., \& Silvestrini, S. (2011). Summary of the synthesis and meta evaluation report: Technical and vocational training. German Technical Cooperation. https://www.giz.de/de/downloads/ giz2013-en-tvet-synthesis-meta-evaluation-2011.pdf

Stufflebeam, D. L. (2000). The CIPP model for evaluation. In D. L. Stufflebeam, G. F. Madaus \& T. Kellaghan (Eds.), Evaluation models: Viewpoints on educational and human services evaluation (pp. 279-317). Kluwer Academic Publishers. https://doi.org/10.1007/0-306-47559-6_16

Tara, S., Kumar, N. S., \& Pilz, M. (2016). Quality of VET in India: The case of industrial training institutes.TVET@Asia, (7).https://www.tvet-online.asia/issue/7/tara-etal

Wallenborn, M. (2010). Vocational education and training and human capital development and future options. European Journal of Education, 45(2), 182-198. https://doi.org/10.1111/j.14653435.2010.01424.x

Wallenborn, M. (2014). Skills development for income generation in rural areas: Can donors learn? Journal of International Development, 26(6), 796-809. https://doi.org/10.1002/jid.1808

Wang, G. G., \& Wilcox, D. (2006). Training evaluation: Knowing more than is practiced. Advances in Developing Human Resources, 8(4), 528-539. https://doi.org/10.1177/1523422306293007

Wessels, A., \& Pilz, M. (2018). Country study India. In P. Grollmann, D. Frommberger, U. Clement, T. Deißinger, U. Lauterbach, M. Pilz \& G. Spöttl (Eds.), International Handbook of Vocational Education and Training, (Issue 50, Volume 24). Federal Institute for Vocational Education and Training. https://www.bibb.de/veroeffentlichungen/de/publication/download/9574

Ziderman, A. (2003). Financing vocational training in Sub-Saharan Africa. World Bank. https://doi. org/10.1596/0-8213-5461-2 


\section{Biographical Notes}

Dr Muthuveeran Ramasamy is a Research Fellow at the Chair of Economics and Business Education at the University of Cologne. He obtained his $\mathrm{PhD}$ from the University of Cologne, Germany. Before to his current position, he worked as Project Director at the Vellore Institute of Technology in India. His research interests are in international VET with the focus on India, skill development, sociology of education and rural development.

Prof Dr Matthias Pilz is Full Professor and holder of the Chair of Economics and Business Education at the University of Cologne. He is also Director of the "German Research Center for Comparative Vocational Education and Training" (G.R.E.A.T.) and the Research Center "G.R.E.A.T. in India". Prior to becoming an academic, he worked as a teacher at a Business College in Hannover and was an advisor for European Union education projects at the district government of Hannover. His research interests are in international comparative research in VET, transitions from education to employment, and teaching and learning. 